\title{
Perancangan Sistem Pakar Dalam Diagnosa Penyakit Varicella Pada Anak Dengan Metode Certainty Factor Berbasis Web
}

\author{
Abdul Rahman Anshar ${ }^{1)}$, Raja Ayu Mahessya S.Kom, M.Kom²), dan Devia Kartika \\ S.Kom, M.Kom ${ }^{3)}$ \\ Universitas Putra Indonesia "YPTK” Padang, Indonesia \\ e-mail: abdulrahmananshar@gmail.com ${ }^{1)}$, ayumahessya @gmail.com ${ }^{2),}$ devia.kartika11@gmail.com ${ }^{3)}$
}

\begin{abstract}
Abstrak
Varicella adalah salah satu penyakit yang mudah menyerang anak anak maupun orang dewasa ataupun ibu hamil. Varicella merupakan suatu gejala penyakit yang disebabkan oleh virus pada makanan dan lingkungan yang dapat diindikasi menjadi suatu penyakit yang akan diderita anak. Varicella dapat menyebar dengan mudah dari orang yang terinfeksi kesiapapun yang belum terkena cacar air sebelumnya dan belum mendapat vaksin cacar air. Di Indonesia penyakit varicella ini kurang menjadi perhatian masyarakat dikarenakan asumsi masyarakat yang menyatakan bahwa varicella akan sembuh sendiri. Oleh karena itu dirancang sebuah sistem pakar untuk mengetahui klasifikasi penyakit varicella pada anak. Metode yang digunakan dalam sistem pakar adalah Certainty Factor. Metode Certainty Factor menggunakan nilai kepastian untuk menguatkan hasil keputusan dari sistem pakar tersebut. Sistem pakar ini dapat memberikan solusi serta cara penanganan penyakit varicella pada anak dengan proses pendiagnosaan dilakukan secara efisien dan menghemat waktu dalam membantu masyarakat atau orang tua dalam pencegahan yang terjadi. Aplikasi sistem pakar berbasis web ini dibangun dengan bahasa pemograman PHP dan penyimpanan data MySQL.
\end{abstract}

Kata kunci: Metode Certainty Factor, MySQL, PHP, Varicella, Sistem Pakar

\begin{abstract}
Varicella is a disease that easily attacks children and adults or pregnant women. Varicella is a symptom of a disease caused by a virus in food and the environment that can be indicated as a disease that will be suffered by a child. Varicella can spread easily from an infected person to anyone who has not been exposed to chickenpox before and has not received a chickenpox vaccine. In Indonesia, varicella disease is of less concern to the public due to the community's assumption that varicella will heal itself. Therefore an expert system was designed to determine the classification of varicella disease in children. The method used in expert systems is Certainty Factor. The Certainty Factor method uses certainty to strengthen the results of decisions from the expert system. Expert system can provide solutions and ways of handling varicella disease in children with the diagnosis process carried out efficiently and saves time in helping the community or parents in prevention that occurs. This web-based expert system application is built with the PHP programming language and MySQL data storage.
\end{abstract}

Keywords: Certainty Factor Methods, MySQL, PHP, Varicella, Expert System.

\section{Pendahuluan}

Varicella adalah penyakit sangat menular yang disebabkan oleh virus. Virus yang menyebabkan penyakit ini adalah virus varicella zozter. Cacar air biasanya tergolong ringan, tetapi dapat berubah menjadi serius jika dialami oleh bayi yang berusia dibawah 12 bulan, 
remaja, orang dewasa, ibu hamil, dan orang dengan kekebalan sistem tubuh yang lemah. Cacar air dapat menyebar dengan mudah dari orang yang terinfeksi kesiapapun yang belum terkena cacar air sebelumnya dan belum mendapat vaksin cacar air. Di Indonesia penyakit varicella ini kurang menjadi perhatian masyarakat dikarenakan asumsi masyarakat yang menyatakan bahwa varicella akan sembuh sendiri. Dimana hendaknya ada sebuah media konsultasi serta pengetahuan yang dapat digunakan masyarakat dalam pencegahan penyakit varicella lebih awal terhadap anak. Untuk membantu mengatasi permasalahan tersebut, maka dirancang suatu sistem pakar diagnosa penyakit varicella pada anak yang dapat meniru cara kerja seorang pakar. Metode yang digunakan adalah metode certainty factor. Hasil pengolahan data berupa faktorfaktor kejadian penyakit varicella yang dimasukkan dan solusi pencegahan lebih awal berdasarkan faktor-faktor yang dimasukkan.

Pada penelitian ini adapun masalah yang timbul di masyarakat pada umumnya adalah kurangnya kesadaran akan dampak dari penyakit varicella yang bisa menyebabkan varicella menjadi penyakit komplikasi jika tidak segera ditangani dan kurangnya pengetahuan akan dampak lebih lanjut dari varicella tersebut. Diharapkan penelitian ini dapat membantu permasalahan yang ada dengan pembuatan sistem pakar yang dapat mendiagnosa penyakit varicella pada anak. Sistem pakar sebagai program yang difungsikan untuk meniru pakar harus bisa melakukan hal-hal yang dapat dikerjakan oleh seorang pakar. Sistem pakar yang akan dirancang menggunakan metode certainty factor (CF) berbasis nilai kepastian atau tingkat keyakinan.

\section{Tinjauan Literatur}

\subsection{Rekayasa Perangkat Lunak}

\subsubsection{Definisi Perangkat Lunak}

Perangkat lunak memiliki beberapa definisi yaitu (Roger S. Pressman, Ph.D, 2012) :

1. Perangkat lunak adalah instruksi-instruksi atau program komputer yang ketika dijalankan menyediakan fitur-fitur, fungsi-fungsi dan kinerja-kinerja yang dikehendaki.

2. Perangkat lunak adalah struktur data yang memungkinkan program-program dalam memanipulasi informasi.

3. Perangkat lunak adalah informasi deskriptif pada salinan tercetak dan bentuk-bentuk maya yang menggambarkan pengoperasian dan penggunaan program-program.

\subsubsection{Definisi Rekayasa Perangkat Lunak}

Rekayasa perangkat lunak (software enginering) merupakan pembangunan dengan mengunakan prinsip atau konsep rekayasa dengan tujuan menghasilkan perangkat lunak yang bernilai ekonomi yang dipercaya dan bekerja secara efisien menggunakan mesin. (Rosa A. S dan M. Shalahuddin, 2014).

\subsection{Definisi Sistem Pakar}

Sistem Pakar adalah program komputer yang menyimulasikan penilaian dan perilaku manusia atau organisasi yang memiliki pengetahuan dan pengalaman ahli dalam bisang tertentu. Biasanya, sistem seperti ini berisi pengetahuan yang berisi akumulasi pengalaman dan satu set aturan untuk menerapkan pengetahuan dasar untuk setiap situasi tertentu. 
Sistem pakar yang canggih dapat ditingkatkan dengan penambahan basis pengetahuan atau set aturan. Di antaranya banyak sistem pakar yang ada, yang terkenal adalah aplikasi bermain catur dan sistem diagnosis medis (Widodo Budiharto, dan Derwin Suharto, 2014).

\subsection{Metode Certainty Factor}

Teori Certainty Factor $(\mathrm{CF})$ mengakomodasi ketidakpastian pemikiran (inexact reasoning) seorang pakar. Seorang pakar (misalnya dokter) seringkali menganalisis informasi yang ada dengan ungkapan seperti "mungkin", "kemungkinanp besar", "hampir pasti". Untuk mengakomodasi hal ini kita menggunakan certainty factor (CF) guna menggambarkan tingkat keyakinan pakar terhadap masalah yang sedang dihadapi. Metode "Net belief" yang diusulkan oleh E.H. Shortliffe dan B.G.Buchanan. (Fakhrul Rahman, Eka Praja Wiyata Mandala, Teri Ade Putra, 2017).

\subsection{Varicella}

Cacar air merupakan infeksi primer oleh Virus Varicella Zoster (VZV), suatu anggota famili Herpesviridae dan patogen langsung pada manusia. Jika ibu hamil terjangkit cacar air akan menambah resiko pada janin berupa kelainan bentuk dan saraf yang parah sehingga bayi mengalami retardasi mental. Bisa juga bayi lahir prematur. Bahkan ibu bisa mengalami komplikasi berupa radang otak atau radang paru. Sekitar $20 \%$ janin dari ibu penderita cacar air beresiko meninggal dunia dalam waktu 5-10 hari setelah dilahirkan (Rukiyah, 2011). Efek dari penyakit ini bagi sang bayi, yaitu : Kerusakan otak, ensefalitis (radang otak), mikrosefal (perkembangan otak terhambat, sehingga otaknya menjadi kecil), hidrosefal (gangguan sirkulasi cairan otak, sehinggga otaknya menjadi besar), aplasia otak. Kerusakan mata, mikro-oftalmik (ukurannya kecil), katarak, korioretinitis, gangguan saraf mata. Gangguan saraf, kerusakan saraf spinal (tulang belakang), gangguan saraf motorik dan sensoris, hilangnya refleks, syndroma horner (Elvalini Warnelis Sinaga, 2018).

\section{Metodologi Penelitian}

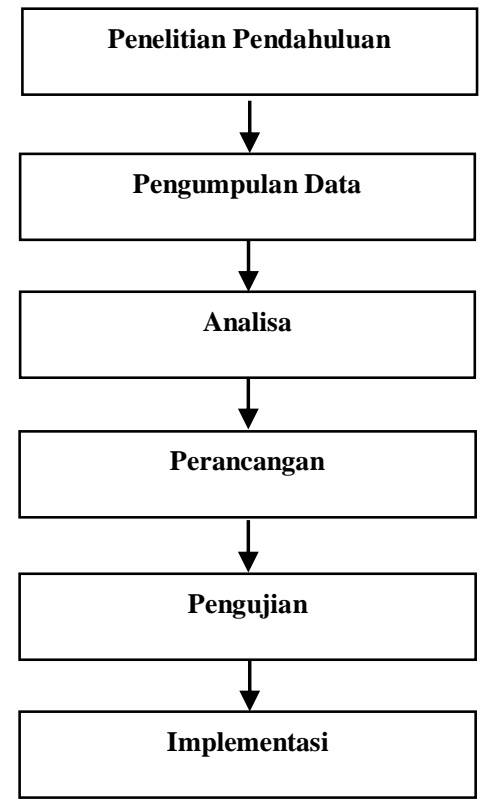




\section{Gambar 3.1 Kerangka Penelitian}

\section{Identifikasi Masalah}

Identifikasi masalah dilakukan dengan melakukan pendekatan terhadap objek penelitian. Tujuan dari tahap ini adalah untuk mengetahui permasalahan yang terjadi secara tepat, sehingga diharapkan penelitian dapat memberikan solusi yang paling optimal terhadap pemecahan permasalahan tersebut.

\section{Melakukan Pengumpulan Data}

Metode pengumpulan data dapat diperoleh secara langsung dari objek penelitian dan referensi-referensi yang telah diperoleh. Cara-cara yang digunakan untuk mendapatkan data adalah melalui studi lapangan dan studi literatur.

\section{Melakukan Analisis}

Analisa ini dilakukan untuk membatasi objek yang akan diteliti agar menjadi sebuah informasi yang lebih sistematis dan mudah dimengerti. Tahap analisa data merupakan tahap yang paling penting dalam pengembangan sebuah sistem.

\section{Perancangan}

Tahap ini menstranslasi kebutuhan perangkat lunak dari tahap analisis kebutuhan ke representasi desain agar dapat diimplementasikan menjadi program, kemudian desain ditranslasikan ke dalam pogram perangkat lunak untuk menghasilkan program komputer yang sesuai dengan hasil yang diharapkan.Untuk menggambarkan alur kerja perancangan perangkat lunak ini, penulis akan memodelkannya menggunakan UML (Unified Modeling Language).

\section{Implementasi}

Implementasi sistem merupakan tahap meletakkan sistem sehingga siap untuk dioperasikan. Implementasi bertujuan untuk mengkonfirmasi modul-modul perancangan, sehingga pengguna dapat memberi masukan kepada pengembangan sistem. Pada tahap ini perancangan sistem dilakukan dengan menggunakan bahasa pemrograman $P H P$ dan MySQLPengujianPengujian fokus pada perangkat lunak dari segi logik dan fungsional dan memastikan bahwa semua bagian sudah bisa bisa memenuhi kebutuhan seperti yang sudah dituliskan pada perumusan masalah, hal ini dilakukan untuk meminimalisir kesalahan (error) dan memastikan keluaran yang dihasilkan sesuai dengan yang diinginkan.

\section{Hasil dan Diskusi}

\subsection{Analisa}

\subsubsection{Analisa Data}

Tahap analisa data merupakan tahap yang paling penting dalam pengembangan sebuah sistem, karena pada tahap inilah nantinya dilakukan evaluasi kinerja, identifikasi terhadap masalah yang ada, rancangan sistem dan langkah - langkah yang dibutuhkan untuk perancangan yang diinginkan sampai pada analisis yang di harapkan.

\subsubsection{Analisa Proses}


Pengetahuan ini akan direpresentasikan dalam bentuk rule yang berguna untuk menemukan kesimpulan terhadap klasifikasi varicella. Pada dasarnya rule terdiri dari dua bagian pokok, yaitu bagian premise atau kondisi dan bagian conclution atau kesimpulan. Struktur rule secara logika menghubungkan satu atau lebih kondisi (premise) pada bagian IF (yang akan menguji kebenaran dari serangkaian data) dengan satu atau lebih kesimpulan (conclution) yang terdapat pada bagian THEN. Adapun cara dalam mendapatkan tingkat keyakinan $(\mathrm{CF})$ dari sebuah rule yang peneliti gunakan, yaitu dengan cara mewancarai seorang pakar.

\subsubsection{Aturan Kaidah (Rule) Berdasarkan nilai CF}

Rule sebuah teknik respentasi pengetahuan sintax rule IF E Then H. Evidence( fakta yang ada) dan hipotesa atau kesimpulan yang dihasilkan.

RULE 1 : IF G1 AND G2 AND G5 AND AND G3 THEN P01 $(\mathrm{CF}=0,6)$

RULE 2 : IF G2 AND G4 AND G5 AND G12 AND G6 THEN P01 $(\mathrm{CF}=0,7)$

RULE 3 : IF G2 AND G4 AND G3 AND G5 AND G8 AND G9 THEN P01 $(\mathrm{CF}=0,7)$

RULE 4 : IF G1 AND G2 AND G4 AND G8 AND G7 AND G9 THEN P01 $(\mathrm{CF}=0,8)$

RULE 5 : IF G1 AND G2 AND G4 AND G3 AND G10 THEN P01 (CF=0,8)

RULE 6 : IF G1 AND G4 AND G5 AND G6 AND G10 THEN P01(CF=0,8)

RULE 7 : IF G1 AND G2 AND G7AND G9 THEN P02 $(\mathrm{CF}=0,6)$

RULE 8 : IF G1 AND G2 AND G6 AND G8 AND G11 THEN P02 (CF=0,7)

RULE 9 : IF G1 AND G2 AND G7 AND G10 THEN P02 (CF=0,8)

RULE 10 : IF G13 AND G8 AND G7 AND G11 THEN P02 (CF=0,7)

RULE 11 : IF G2 AND G6 AND G13 AND G8 AND G7 THEN P02 (CF=0,7)

RULE 12 : IF G1 AND G3 AND G11 AND G14 THEN P03 $(\mathrm{CF}=0,8)$

RULE 13 : IF G3 AND G13 AND G8 AND G14 AND G15 THEN P03 (CF=0,8)

RULE 14 : IF G3 AND G6 AND G13 AND G11 AND G14 AND G15 THEN P03 $(\mathrm{CF}=0,8)$

Keterangan setiap rule dari fakta baru :

RULE 1 : IF G1 (CF=0.5) AND G2(CF=0.4) AND G5(CF=0.6) AND G3(CF=0.6) THEN P01 $(\mathrm{CF}=0,6)$

$\mathrm{CF} 1(\mathrm{P} 01, \mathrm{G} 01 \cap \mathrm{G} 02 \cap \mathrm{G} 05 \cap \mathrm{G} 03)$

$$
\begin{aligned}
& =\operatorname{Min}[0.5 ; 0.4 ; 0.6 ; 0.6] * 0.6 \\
= & 0.24
\end{aligned}
$$

RULE 2 : IF G2(CF=0.4) AND G4(CF=0.5) AND G5(CF=0.6) AND G12(CF=0.4)

AND G6(CF=0.5) THEN P01 $(\mathrm{CF}=0,7)$

$\mathrm{CF} 2(\mathrm{P} 01, \mathrm{G} 02 \cap \mathrm{G} 04 \curvearrowright \mathrm{G} 05 \cap \mathrm{G} 12 \cap \mathrm{G} 06)$

$$
=\min (0,4 ; 0,5 ; 0,6 ; 0,4 ; 0,5 ; 0,8) * 0,7
$$

$=0,28$

RULE 3 : IF G2(CF=0.4) AND G4(CF=0.5) AND G3(CF=0.6) AND G5(CF=0.6)

AND G8(CF=0.8) AND G9(CF=0.6) THEN P01 $(\mathrm{CF}=0,7)$

$\mathrm{CF} 3(\mathrm{P} 01, \mathrm{G} 02 \curvearrowright \mathrm{G} 04 \curvearrowright \mathrm{G} 03 \curvearrowright \mathrm{G} 05 \curvearrowright \mathrm{G} 08 \curvearrowright \mathrm{G} 09)$

$=\min (0,4 ; 0,5 ; 0,6 ; 0,6 ; 0,8 ; 0,6) * 0,7$

$=0,28$

RULE 4 : IF G1 $(\mathrm{CF}=0.5)$ AND G2(CF=0.4) AND G4(CF=0.5) AND G8(CF=0.8)

AND G7 $(\mathrm{CF}=0.8)$ AND G9(CF=0.6) THEN P01 $(\mathrm{CF}=0,8)$ 


$$
\begin{aligned}
& \mathrm{CF} 4(\mathrm{P} 01, \mathrm{G} 01 \cap \mathrm{G} 02 \cap \mathrm{G} 04 \cap \mathrm{G} 08 \cap \mathrm{G} 07 \cap \mathrm{G} 09) \\
& =\min (0,5 ; 0,4 ; 0,5 ; 0,8 ; 08 ; 0,6) * 0,8 \\
& \quad=0,32
\end{aligned}
$$

RULE 5 : IF G1(CF=0.5)AND G2(CF=0.4)AND G4(CF=0.5)AND G3(CF=0.6)AND $\mathrm{G} 10(\mathrm{CF}=0.9)$ THEN P01 $(\mathrm{CF}=0,8)$

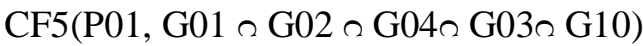

$=\min (0,5 ; 0,4 ; 0,5 ; 0,6 ; 0,9) * 0,8$

$$
=0,32
$$

RULE 6 : IF G1(CF=0.5)AND G4(CF=0.6)AND G5(CF=0.6)AND G6(CF=0.5)AND $\mathrm{G} 10(\mathrm{CF}=0.9)$ THEN P01 $(\mathrm{CF}=0,8)$

$\mathrm{CF} 6(\mathrm{P} 01, \mathrm{G} 01 \cap \mathrm{G} 04 \cap \mathrm{G} 05 \cap \mathrm{G} 06 \curvearrowright \mathrm{G} 10)$

$$
\begin{aligned}
& =\min (0,5 ; 0,5 ; 0,6 ; 0,5 ; 0,9) * 0,8 \\
& =0,40
\end{aligned}
$$

RULE 7 : IF G1(CF=0.5) AND G2(CF=0.4)AND G7(CF=0.8)AND G9(CF=0.6)

THEN P02 $(\mathrm{CF}=0,6)$

$\mathrm{CF} 7(\mathrm{P} 02, \mathrm{G} 01 \cap \mathrm{G} 02$ ○ G07^ G09)

$$
\begin{aligned}
& =\min (0,5 ; 0,4 ; 0,8 ; 0,8 ; 0,6) * 0,6 \\
& =0,24
\end{aligned}
$$

RULE 8 : IF G1(CF=0.5) AND G2(CF=0.4)AND G6(CF=0.5)AND G8(CF=0.8)AND $\mathrm{G} 11(\mathrm{CF}=0.5)$ THEN P02 (CF=0,7)

$\mathrm{CF} 8(\mathrm{P} 02, \mathrm{G} 01 \cap \mathrm{G} 02 \cap \mathrm{G} 06 \curvearrowright \mathrm{G} 08 \cap \mathrm{G} 11)$

$$
\begin{aligned}
& =\min (0,5 ; 0,4 ; 0,5 ; 0,8 ; 0,5) * 0,7 \\
& =0,28
\end{aligned}
$$

RULE 9 : IF G1(CF=0.5)AND G2(CF=0.4)AND G7(CF=0.8)AND G10(CF=0.9)

THEN P02 $(\mathrm{CF}=0,8)$

$\mathrm{CF} 9(\mathrm{P} 02, \mathrm{G} 01 \cap \mathrm{G} 02 \cap \mathrm{G} 07 \cap \mathrm{G} 10)$

$=\min (0,5 ; 0,4 ; 0,8 ; 0,8 ; 0,9) * 0,8$

$=0,32$

RULE 10 : IF G13(CF=0.7)AND G8(CF=0.8)AND G7(CF=0.8)AND G11(CF=0.5) THEN P02 $(\mathrm{CF}=0,7)$

$\mathrm{CF} 10(\mathrm{P} 02, \mathrm{G} 13 \cap \mathrm{G} 08$ ○ G07^ G11)

$$
=\min (0,7 ; 0,8 ; 0,8 ; 0,5) * 0,7
$$

$=0,3$

RULE 11 : IF G2(CF=0.4)AND G6(CF=0.5)AND G13(CF=0.7)AND

$\mathrm{G} 8(\mathrm{CF}=0.8)$ AND $\mathrm{G} 7(\mathrm{CF}=0.8)$ THEN P02 ( $\mathrm{CF}=0,7)$

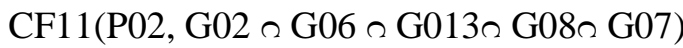

$$
=\min (0,4 ; 0,5 ; 0,7 ; 0,8 ; 0,8) * 0,7
$$

$=0,28$

RULE 12 : IF G1(CF=0.5)AND G3(CF=0.6)AND G11(CF=0.5)AND G14 $(\mathrm{CF}=0.8)$ THEN $\mathrm{P} 03(\mathrm{CF}=0,8)$

$\mathrm{CF} 12(\mathrm{P} 03, \mathrm{G} 01 \cap \mathrm{G} 03$ ○ $\mathrm{G} 11 \cap \mathrm{G} 14)$

$$
=\min (0,5 ; 0,6 ; 0,5 ; 0,8) * 0,8
$$

$=0,40$

RULE 13 : IF G3(CF=0.6)AND G13(CF=0.7)AND G8(CF=0.8)AND

$\mathrm{G} 14(\mathrm{CF}=0.8)$ AND G15(CF=0.4)THEN P03 $(\mathrm{CF}=0,8)$

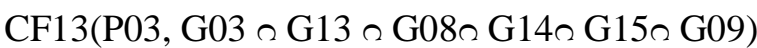




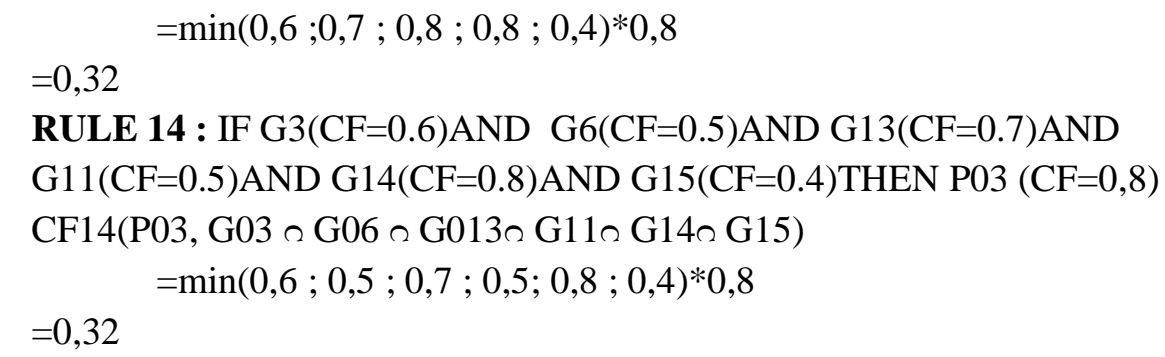

\section{CF Gabungan Dari Rule :}

Karena Rule 1, Rule 2, Rule 3, Rule 4, Rule 5 dan Rule6 Hipotesanya sama yaitu P01, maka CF digabungkan :

$$
\begin{aligned}
\text { CFgab } & =\text { CF } 1+\text { CF2 } \times(1-\text { CF } 1) \\
& =0.24+0.28 \times(1-0.24) \\
& =0.4528 \\
\text { CFakhir } 1=\text { CFGab }+ \text { CF3 } \times(1-C F G a b) & =0.4528+0.28 \times(1-0.4528) \\
& =0.606 \\
\text { CFgab } & =\text { CF } 4+\text { CF5 } \times(1-\text { CF4 }) \\
& =0.32+0.32 \times(1-0.32) \\
& =0.5376 \\
\text { CFakhir2 } & =\text { CFGab }+ \text { CF6 } \times(1-C F G a b) \\
& =0.5376+0.40 \times(1-0.5376) \\
& =0.7225
\end{aligned}
$$

CFCombine $=\mathrm{Cf}$ akhir $1+$ Cfakhir $2 \times(1-$ Cfakhir 1$)$

$$
\begin{aligned}
& =0.606+0.7225 \times(1-0.606) \\
& =0.8906
\end{aligned}
$$

Karena Rule 7, Rule 8, Rule 9, Rule 10 dan Rule11 Hipotesanya sama yaitu $\mathrm{P} 02$, maka CF digabungkan :

$$
\begin{aligned}
\text { CFgab } & =\text { CF7 }+ \text { CF8 } \times(1-\text { CF7 }) \\
& =0.24+0.28 \times(1-0.24) \\
& =0.4528 \\
\text { CFakhir } 1=\text { CFGab }+ \text { CF9 } \times(1-C F G a b) & \\
& =0.4528+0.32 \times(1-0.4528) \\
& =0.627 \\
\text { CFgab } & =\text { CF10 }+ \text { CF1 } 1 \times(1-\text { CF10 }) \\
& =0.35+0.28 \times(1-0.35) \\
& =0.532
\end{aligned}
$$

Cfcombine $=$ Cfakhir $1+$ CFGab $\times(1-$ Cfakhir 1$)$

$$
\begin{aligned}
& =0.627+0.532 \times(1-0.627) \\
& =0.8254
\end{aligned}
$$

Karena Rule 12, Rule 13 dan Rule14 Hipotesanya sama yaitu P03, maka CF digabungkan

$$
\begin{aligned}
\text { CFgab } & =\text { CF12 }+ \text { CF13 } \times(1-\text { CF12 }) \\
& =0.40+0.32 \times(1-0.40) \\
& =0.592 \\
\text { CFakhirl } & =\text { CFGab }+ \text { CF14 } \times(1-C F G a b) \\
& =0.592+0.32 \times(1-0.592)
\end{aligned}
$$




$$
=0.7225
$$

Fakta Baru :

$\mathrm{P} 01$ Hypothesis $\mathrm{CF}=0.8906$

$\mathrm{P} 02$ Hypothesis $\mathrm{CF}=0.8254$

$\mathrm{P} 03$ Hypothesis $\mathrm{CF}=0.7225$

\section{Kesimpulan :}

Penyakit yang di derita oleh User adalah :

Varicella Stadium Prodomal Tingkat Kepastian $=0.89$ atau $89 \%$.

\subsubsection{Analisa Sistem}

Tahap analisa system ini akan memperlihatkan bagaimana sistem pakar yang akan di buat.Apakah perancangan dari kinerja sistem iniakanmembantu user dengan permasalahan yang dihadapinya atau user akan lebih merasa bingung tentang informasi yg diberikan. Nantinya di dalam sistem pakar yang di buat, seorang user non member dapat mengakses sistem yang terdapat beberapa menu diantaranya menu home yang berisi sekilas tentang sistem pakar, menu varicella yang berisi keterangan varicellatersebut, menu register yang berisi halaman untuk melakukan konsultasi, menu login yang digunakan untuk login ke sistem, dan menu bantuan yang berisi halaman bantuan penggunaan sistem. Seorang member dapat mengakses sistem dengan menu yaitu home yang berisi sekilas tentang sistem pakar, menu varicella yang berisi keterangan varicella menu konsultasi berisi halaman untuk konsultasi, dan menu bantuan yang berisi halaman bantuan penggunaan sistem. Seorang admin mempunyai menu di antara lain adalah, menu home berisi halaman selamat datang, menu kelola gejala berisi halaman untuk mengelola gejala, menu kelola penyakit berisi halaman untuk mengelola penyakit, menu kelola member berisi halaman untuk mengelola member, menu hasil konsultasi untuk melihat hasil konsultasi.

\subsection{Perancangan}

Perancangan dimulai dengan mengumpulkan data-data dan fakta-fakta yang mendukung perancangan sistem dengan mengadakan konsultasi bersama pakar. Selanjutnya akan dilakukan tahap perancangan yang terbagi menjadi perancangan model dan perancangan interface. Perancangan model terdiri dari 7 diagram Unified Modelling Language yang menggambarkan sistem yang di buat, sedangkan perancangan interface merupakan gambaran interface sistem yang di buat dalam penelitian ini.

\subsubsection{Perancangan Model}

Adapun perancangan model Unified Modeling Language dalam penelitian ini adalah sebagai berikut:

\subsubsection{Use Case Diagram}

Use case diagram digunakan untuk menjelaskan tentang interaksi aktor yang ada dengan sistem yang di buat, interaksi ini mengacu kepada case yang ada pada sistem tersebut 


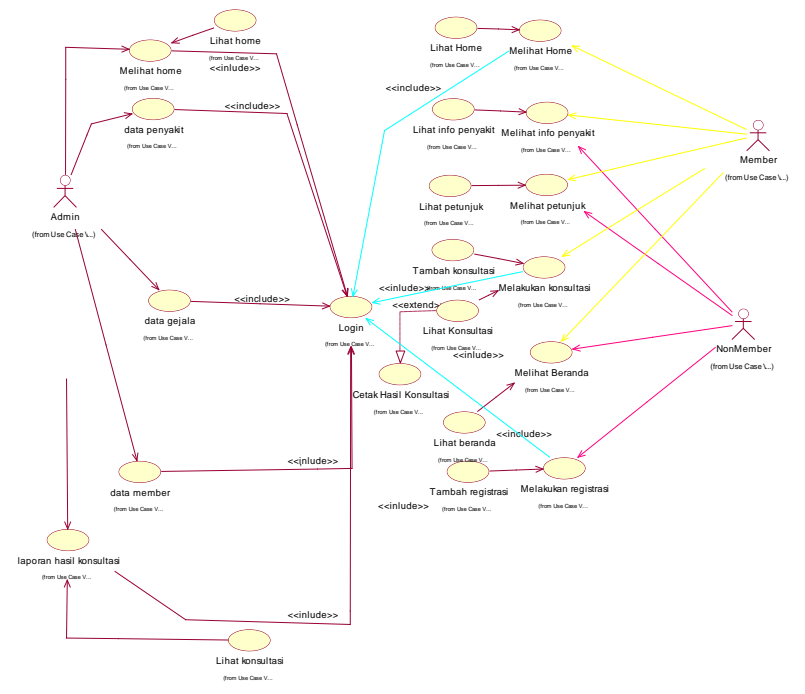

Gambar 4.1 Use Case Diagram Member, Non Member, Admin

\section{IMPLEMENTASI DAN PENGUJIAN}

\subsection{Implementasi Sistem}

Implementasi sistem dilakukan setelah melakukan perancangan sistem pakar. Implementasi sistem dapat dilakukan setelah sistem pakar yang dibuat dapat berjalan sebagaimana mestinya.Untuk itu pada bab ini akan dijelaskan bentuk asli dari tampilan sebenarnya apabila sistem ini diakses oleh user.

\subsection{Layout Website}

1. Tampilan Halaman Home

Pada halaman ini ditampilkan halaman untuk memilih menu dari beberapa pilihan yang terdapat pada halaman home.Pada halaman ini terdapat beberapa menu yang dapat diperoleh.Pada menutersebut ada beberapa pilihan diantaranya :Menu home, penyakit varicella, register, login, dan bantuan penggunaan. Dan setelah login akan terdapat 2 buah menu tambahan yaitu konsultasi dan pengiriman pesan.

Gambar halaman home dapat dilihat pada gambardibawah ini :

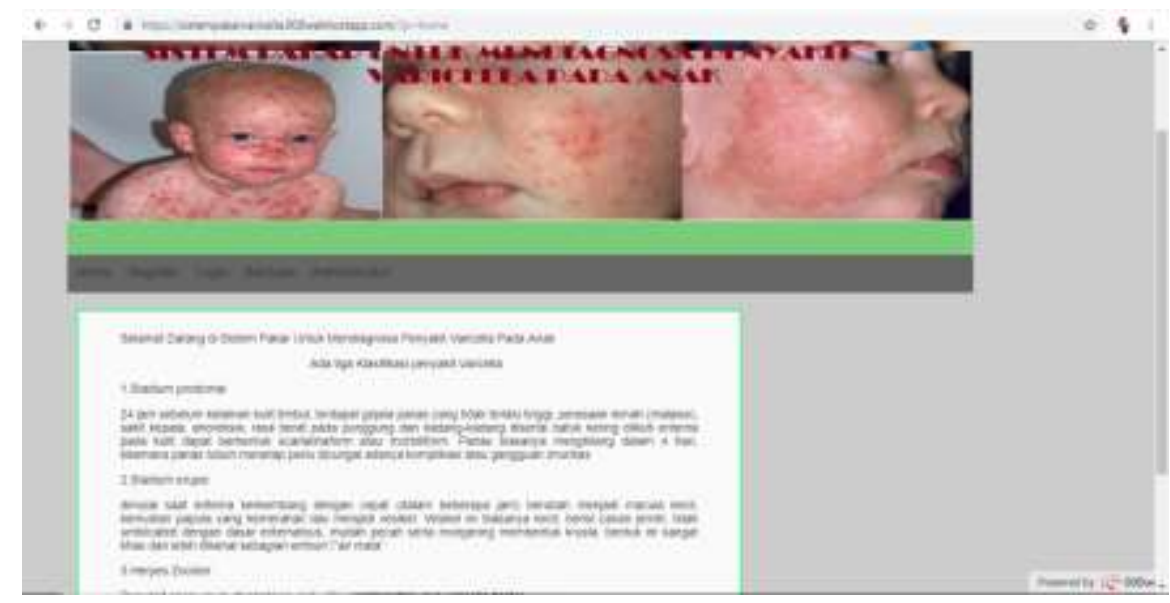




\section{Gambar 5.1 Layout Halaman Home}

Gambar di atas merupakan tampilan dari menu home pada halaman awal dari sistem yang di buat, dimana terdapat penjelasan tentang apa itu sistem pakar.

2. Tampilan Halaman Penyakit Varicella.

Halaman Penyakit Varicella berisikan informasi mengenai penyakit varicella yang bisa di deteksi dari sistem pakar ini.

Gambar halaman penyakit varicella dapat dilihat pada gambar berikut:

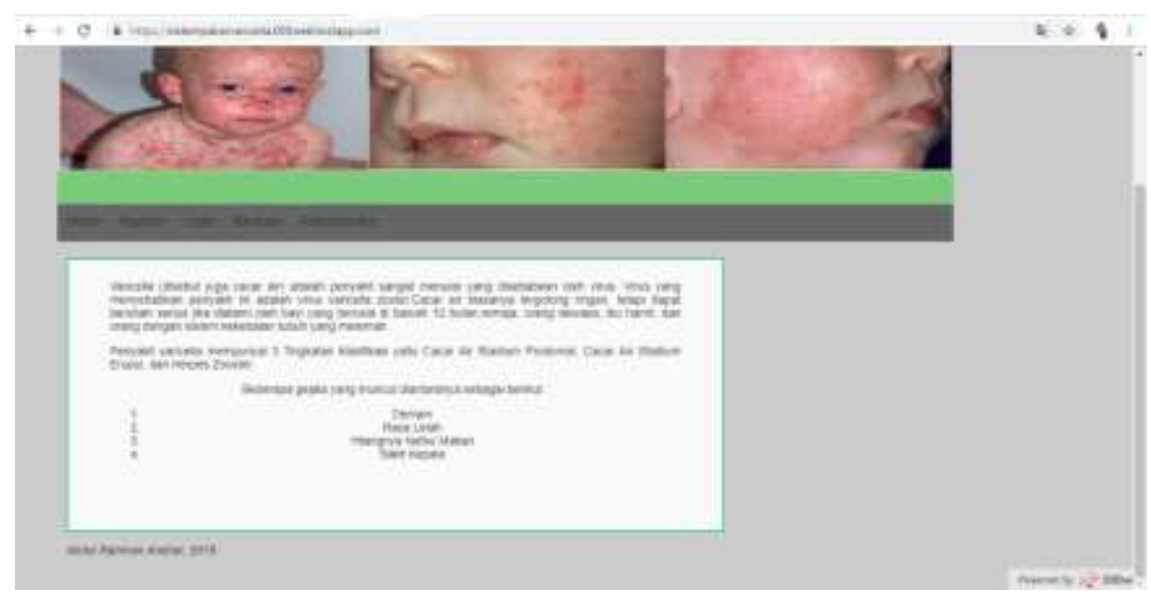

Gambar 5.2 Layout Halaman Penyakit Varicella

Gambar 5.2 merupakan tampilan halaman penyakit varicella yang berisi sedikit penjelasan tentang penyakit varicella beserta gejala-gejala yang ada, seperti nama, keterangan, gejala, dan penanggulangan dari penyakit.

3. Tampilan Halaman Register User

Halaman register user berisikan tampilan dimana seorang user yang belum menjadi memberdapat mengisi data pribadinya agar memiliki account sendiri, pada halamn ini user dapat mengisikan data diri sepertiusername, password, nama,jenis kelamin, alamat.

Gambar halaman registrasi dapat dilihat pada gambar berikut: 


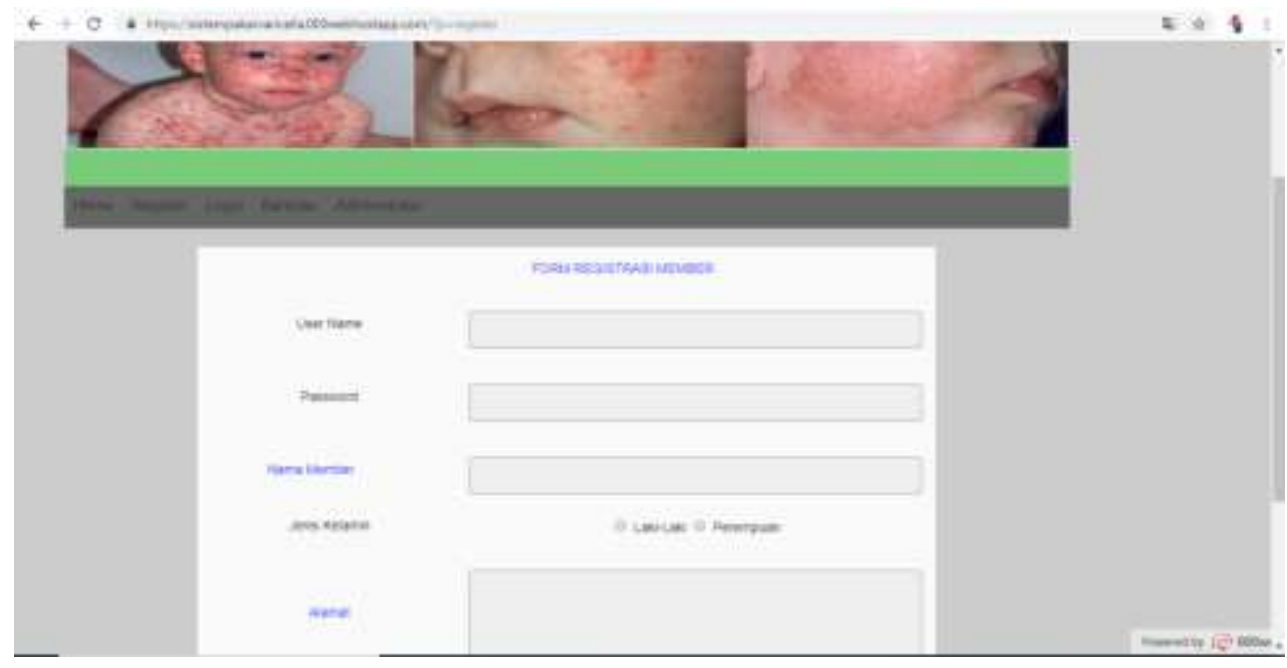

Gambar 5.3 Layout halaman Register

Gambar 5.3 merupakan tampilam halaman register dimana seorang user dapat mengisi data diri dan melakukan registrasi untuk selanjutnya melakukan login.

\section{Tampilan HalamanLogin Member}

Halaman ini berisikan menu login bagi user yang telah menjadi member dari sistem.

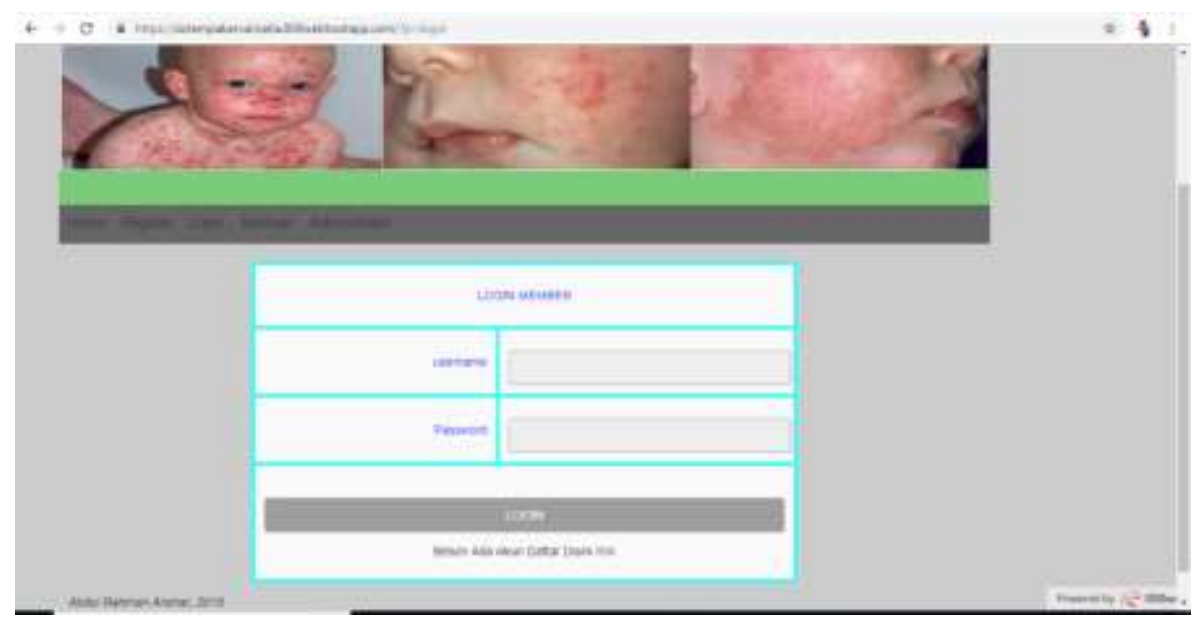

\section{Gambar 5.4 Layout Halaman Login Member}

Gambar 5.4 merupakan tampilan halaman login yang terdapat form username dan password yang harus diisi oleh member untuk melakuan login.

\section{Tampilan Data Konsultasi}

Setelah melakukan login, akan terdapat sebuah menu baru yaitu menu konsultasi dimana member dapat melakukan konsultasi pada halaman tersebut. 


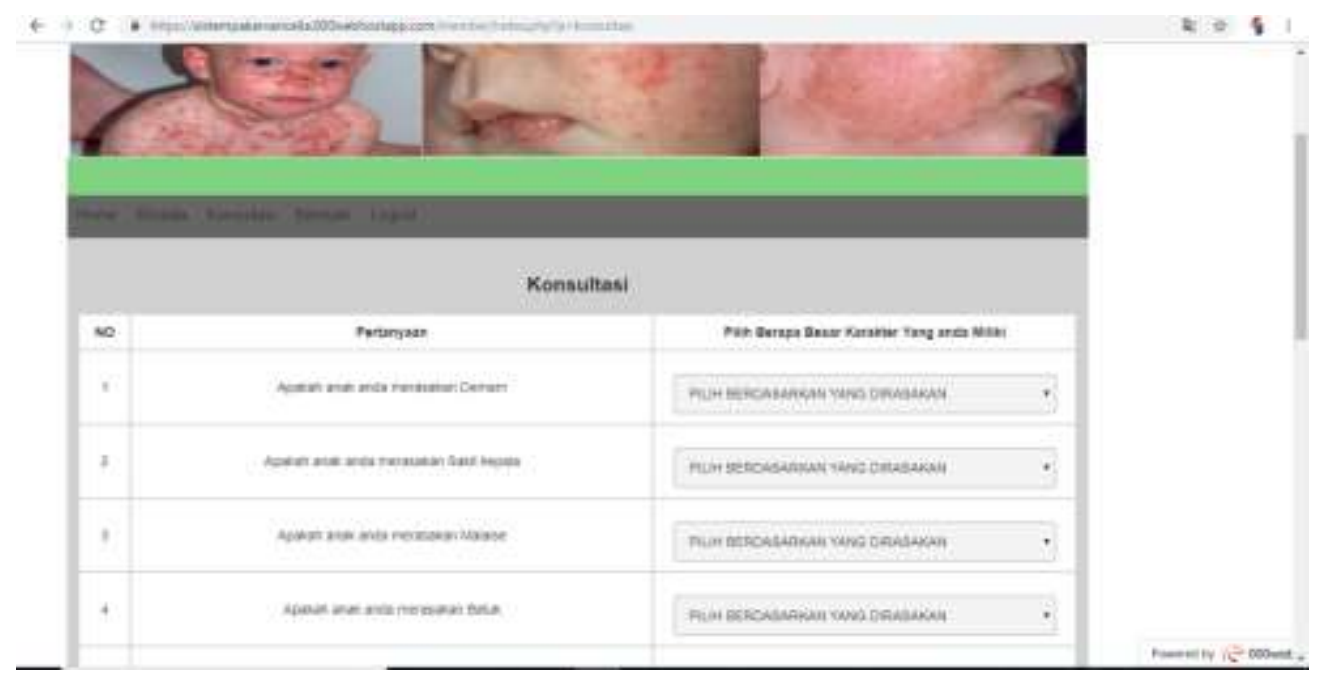

Gambar 5.5 Layout Halaman Konsultasi

Gambar 5.5 merupakan tampilan halaman konsultasi dimana member yang ingin melakukan konsultasi akan mengisi data gejala dan kemungkinan dari keyakinan member.

6. Tampilan Hasil dari Konsultasi

Tampilan ini merupakan tampilan yang akan muncul setelah konsultasi dilakukan, dimana setelah menekan tombol konsultasi, member akan di alihkan ke halaman hasil yang berisi gejala, hasil diagnosa, serta proses dari perhitungan konsultasi.

Gambar dari halaman hasil konsultasi dapat dilihat pada gambar berikut:

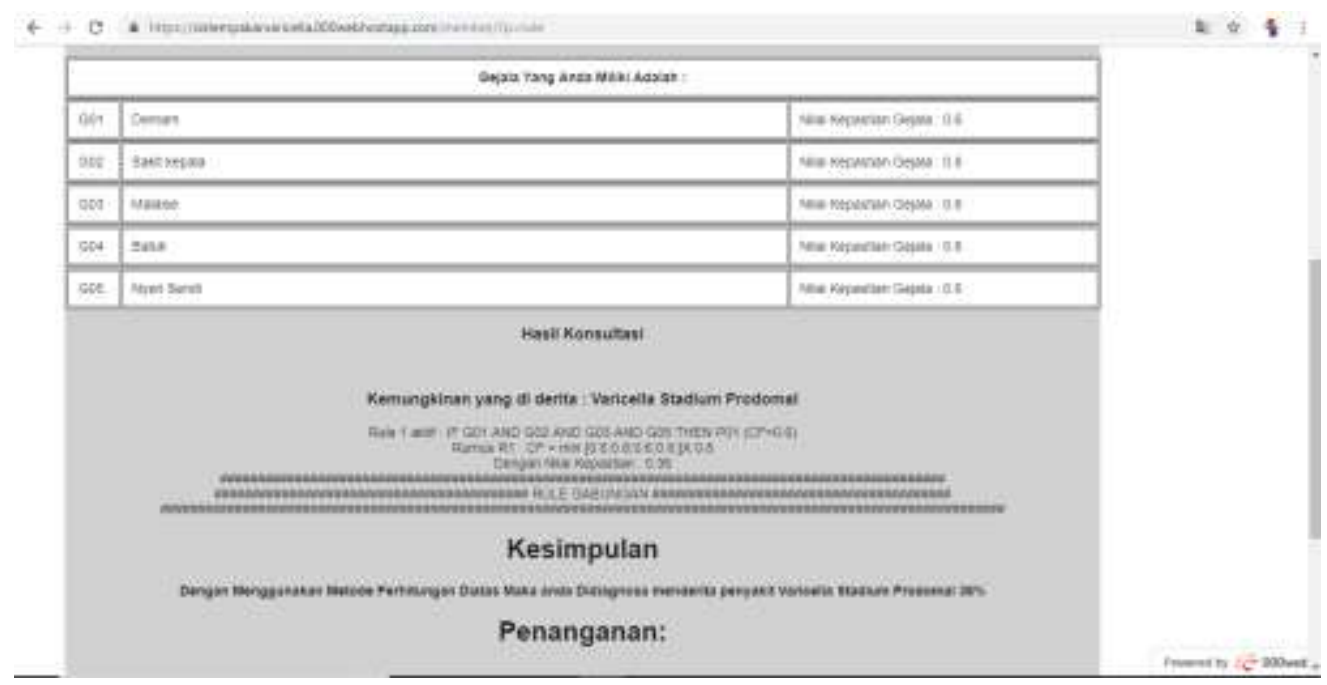

\section{Gambar 5.6 Tampilan Hasil Konsultasi}

\section{Kesimpulan}

\subsection{Kesimpulan}

Dari uraian masalah di atas, serta berdasarkan analisa dari bab-bab yang ada, maka dapat ditarik kesimpulan sebagai berikut: 
1. Dengan menggunakan aplikasi sistem pakar, dapat mempermudah masyarakat dalam melakukan pendiagnosaan lebih awal penyakit varicella pada anak. Dengan pengetahuan yang diberikan oleh sistem, pengguna mendapatkan pengetahuan tentang varicella serta bahaya yang ditimbulkan dari varicella tersebut.

2. Dengan cara membuat aplikasi sistem pakar dengan menggunakan php mysql ini, dapat digunakan dengan mudah dan evisien yang kana memberikan pengetahuan atau hasil diagnosa yang tepat kepada pengguna.

3. Dengan adanya aplikasi sistem pakar, maka dapat memberikan pengetahuan gejalagejala yang ditimbulkan oleh penyakit varicella pada anak.

\section{DAFTAR PUSTAKA}

[1] Budiharto, Widodo dan Derwin Suhartono. "Artificial Intelligence Konsep dan Penerapan." Andi : Yogyakarta. (2014).

[2] Mandala, Eka Praja Wiyata. "Web Programing Project 1: epwm forum," Yogyakarta: CV.ANDI OFFSET (2015).

[3] Maudi, Meiska Fristiara, Arief Laila Nugraha, and Bandi Sasmito. "Desain Aplikasi Sistem Informasi Pelanggan PDAM Berbasis WebGIS (Studi Kasus: Kota Demak)." Jurnal Geodesi Undip 3.3 (2014): 98-110.

[4] Pace, David. "Review of Varicella zoster virus: from epidemiology to prevention." (2008).

[5] Pressman, Roger S, Ph.D. "Rekayasa Perangkat Lunak." Andi : Yogyakarta. (2012).

[6] Rahman, Fakhrul. " Perancangan Aplikasi Sistem Pakar Dengan Menggunakan Metode Certainty Factor Untuk Menentukan Jenis Gnagguan Disleksia Berbasis Web." Jurnal INKOFAR 1.1 (2017).

[7] Sarwono, Jonathan. "Metode Riset Online," Jakarta : PT Elex Media Komputindo (2015).

[8] Sasmito, Ginanjar Wiro. "Penerapan Metode Waterfall Pada Desain Sistem Informasi Geografis Industri Kabupaten Tegal." Jurnal Informatika: Jurnal Pengembangan IT 2.1 (2017): 6-12.

[9] S, Rosa A dan M. Shalahuddin. "Modul Pembelajaran Rekayasa Perangkat Lunak (Terstruktur dan Berorientasi Objek)." Bandung: Informatika. (2013).

[10] Sinaga, Elvalini Warnelis. "Tingkat Pengetahuan Ibu Hamil Tentang Bahaya Varicella Selama Kehamilan Di Kelurahan Sicanang Kecamatan Medan Belawan Tahun 2018." Jurnal Ilmiah Kebidanan Imelda 4.2 (2018).

[11] Suhartanto, Medi. "pembuatan website sekolah menengah pertama negeri 3 delanggu dengan menggunakan php dan mysql." Speed-Sentra Penelitian Engineering dan Edukasi 4.1 (2017).

[12] Sutojo, T, Edy Mulyanto dan Vincent Suhartono. "Kecardasan Buatan." Andi : Yogyakarta. (2011).

[13] Wijaya, Edi. "Analisis Penggunaan Algoritma Breadth First Search Dalam Konsep Artificial Intellegencia." Jurnal TIMES 2.2 (2013).

[14] Winanto, Tomi, Yustina Retno Wahyu Utami, and Sri Hariyati Fitriasih. " Sistem Pakar Diagnosa Hama dan Penyakit Tanaman Cabai Besar Menggunakan Metode Crtainty Factor." Jurnal Ilmiah SINUS 15.2 (2017)

[15] Harto, Dodi. "Perancangan Sistem Pakar Untuk Mengidentifikasi Penyakit Pada Tanaman Semangka Dengan Menggunakan Metode Certainty Factor." Pelita Informatika Budi Darma 4.2 (2013): 26-35. 
[16] Hasanah, Izatul, Retno Devita, and Devia Kartika. "Perancangan Sistem Pakar Untuk Mendiagnosa Kehamilan Ektopik Pada Rumah Sakit Bersalin Yasmin Solok Menggunakan Metode Forward Chaining Berbasis Web." Komputer Teknologi Informasi 3.2 (2016).

[17] Hendini, Ade. "Pemodelan Uml Sistem Informasi Monitoring Penjualan dan Stok Barang (Studi Kasus: Distro Zhezha Pontianak)." Jurnal Khatulistiwa Informatika 4.2 (2016). 